\author{
SILVIA LANDI $(*)$ - FABRIZIO PENNACCHIO $(*)$ - ROSSELLA PAPINI $(*)$ - GIADA D’ERRICO $(* *)$ \\ GIULIA TORRINI $(*)$ - AGOSTINO STRANGI $\left(^{*}\right)$ - DELFINA BARABASCHI $(* * *)$ - PIO FEDERICO ROVERSI $(*)$
}

\title{
EVALUATION OF SHEEP GRAZING EFFECTS ON NEMATODE COMMUNITY, INSECT INFESTATION AND SOIL FERTILITY IN SWEET CHESTNUT ORCHARDS: A CASE OF STUDY
}

\author{
(*) Council for Agricultural Research and Economics - Agrobiology and Pedology Research Centre (CREA-ABP), Via \\ di Lanciola 12/A, Cascine del Riccio, 50125 Firenze, Italy; e-mail: silvia.landi@crea.gov.it \\ (**) University of Naples Federico II, Via Università 100, 80055 Portici, Napoli, Italy \\ (***) Council for Agricultural Research and Economics - Genomics Research Centre (CREA-GPG), Via S. Protaso 302, \\ 29017 Fiorenzuola d'Arda (PC), Italy
}

Landi S., Pennacchio F., Papini R., d'Errico G., Torrini G., Strangi A., Barabaschi D., Roversi P.F. - Evaluation of sheep grazing effects on nematode community, insect infestation and soil fertility in sweet chestnut orchards: a case of study.

In sweet chestnut cultivation, important ecosystem in Europe, the moderate sheep grazing practice may have some beneficial effects in organic farming. Its impact, on soil fertility, soil nematode community and level of fruit infested by tortricids and curculionids was evaluated in a case of study in Tuscany (Central Italy). An organic farm with sheep grazing system (SG) based on long-term field application was compared with an adjacent organic farm with poultry manure system (PM). In both managements, no treatment to control pests and diseases was applied and $0.19 \mathrm{~kg} / \mathrm{plant}$ of nitrogen were distributed. SG increased twice the amount of organic $\mathrm{C}$, total $\mathrm{N}$ and available $\mathrm{P}$ than PM. Moreover, the salinity effect of uric acid significantly increased the $\mathrm{pH}$ values in SG (from 5.0 to 6.2). The greatest accumulation of organic matter under SG provided stability in nematode community structure and the plant parasitic nematodes decreased. The analysis on the nematodes emerged from Galleria mellonella larvae, revealed that the abundance of native entomopathogenic nematodes was low and not effective to control insect pests. The sheep demonstrated to be the effective predators of tortricid and weevil larvae and in November, the total infestation was significantly lower in SG (34.3\%) than PM $(54.3 \%)$

KEY WoRDS: Organic matter, nematode indicators, entomopathogenic nematodes, tortricids, curculionids

\section{INTRODUCTION}

Sweet chestnut (Castanea sativa Mill.) stands and orchards are very common around the western Mediterranean basin. In Europe, chestnut plantation for fruit production is an important agro-ecosystem covering a surface area of $117,000 \mathrm{ha}$, the Mediterranean area is representing a significant part around 110,000 ha, which is $94 \%$ of total Europe and $33 \%$ of the total world chestnut area (FAO, 2004). Recently, the growing demand for traditional foods has generated a considerable interest in chestnut (BouNOUS, 2004), and today six geographical areas in Italy are regulated by Protected Geographic Indication (PGI) under European Union law (NeRI et al., 2010).

In Tuscany (north-central Italy), currently all sweet chestnut land is under organic farming (L.R. 39/2000). Organic agriculture continues to be advanced as a viable and sustainable alternative to conventional agriculture, reducing the environmental impacts of agricultural practices, and providing eco-friendly production to the population. In this context, moderate grazing by livestock is known as a practice that with defecation effect may result in enhancing soil quality and fertility (DENNIS et al., 1998; Cole et al., 2010). The monitoring of soil nematofauna represents an efficient tool to characterize the effects of crop management by assessing the biological soil quality (Bongers, 1990; FERris et al., 2001). Soil nematodes occupy important positions in the detritus food web, the graze on bacteria and fungi in soil, and thus may regulate decomposition and nitrogen mineralization in soil ecosystem. Moreover, phylum Nematoda includes a group of entomopathogenic nematodes (EPNs) principally belonging to Steinernema and Heterorhabditis genera that possess attributes for the biological control of many soilinhabiting insects (GAUGLER, 2002; VINCIGUERRA and Clausi, 2006).

Additionally, livestock grazing have potential importance for the pest control, such as tortricids (Cydia spp.) and curculionids (Curculio spp.), which can cause losses up to $50 \%$ of the fruit production (PAPARATTI and SPERANZA, 2004; Aguin-PomBo et al., 2008). In general, the natural enemies of tortricids and curculionids, such as predators, parasitoids and EPNs, may limit their population growth and thus their negative effects on plants (BERRYMAN, 1996; MoOn and Stiling, 2002; Strauss and ZANGerl, 2002), but phytophagous insects may also be eaten by herbivores. In temperate areas, infested fruits are prematurely abscised (BOUCHER and SORK, 1979) and larvae complete their growth inside them on the ground, making them vulnerable to incidental predation by large herbivores (BONAL and MUÑOZ, 2007).

The aim of this study was to evaluate the effect of a moderate livestock grazing regime in a case of study in sweet chestnut cultivation in Tuscany. An organic sheep grazing system based on long-term field application was compared with an adjacent organic poultry manure system. We 
specifically evaluated the effects of animals on: (1) the soil fertility, (2) the soil nematode community, and (3) the fruit infestation levels by tortricids and curculionids. Moreover, the dynamics of nematode communities, their relationships to indicators of soil condition and the trend of tortricids and curculionids were achieved by multiple sampling points.

\section{MATERIALS AND METHODS}

SITE AND TREATMENT DESCRIPTION

The study site is situated at Marradi (Florence, central Italy) at $558 \mathrm{~m}$ a.s.l. In the area, the long-term annual air mean temperature is $12^{\circ} \mathrm{C}$ with average maximum temperatures in July $\left(21.8^{\circ} \mathrm{C}\right)$ and average minimum temperatures in January $\left(2.4^{\circ} \mathrm{C}\right)$. The mean annual precipitation is $843 \mathrm{~mm}$ with the higher rainfall in January $(104 \mathrm{~mm})$ and the driest month is July $(46 \mathrm{~mm})$. The soil texture was classified as silt-loam with $23.80 \%$ (standard error 4.02 ) of sand, $48.57 \%$ (4.22) of silt and $27.65 \%$ (4.02) of clay. This investigation was undertaken in two adjacent organic farms based on a long-term cultivation of sweet chestnut (30 years), ecotype "Marrone di Marradi", which is marketed under the "Marrone del Mugello" PGI trademark (60 trees/ha).The major difference between the two organic farming was the use of the sheep grazing (SG) in one $\left(44^{\circ} 02^{\prime} 45.67^{\prime \prime} \mathrm{N}, 11^{\circ} 36^{\prime} 27.81^{\prime \prime} \mathrm{E}\right)$ and the use of poultry manure (PM) in the other $\left(44^{\circ} 02^{\prime} 04.91^{\prime \prime} \mathrm{N}, 11^{\circ} 36^{\prime} 54.15^{\prime} \mathrm{E}\right)$. In both managements, no treatment to control pests and diseases was applied and the nitrogen distributed to each plant corresponded to $0.19 \mathrm{~kg}$. SG was grazed by 5 units per ha per year (Suffolk hybrid), while $8 \mathrm{~kg} /$ plant of poultry manure was applied like a localized mineral fertilizer on crown cover in PM.

\section{SAMPLING}

The field experiment was set up in 2014. The same experimental design was carried out in both farms. The total area of each farm was 2.0 ha consisting of five plots $(0.4$ ha per plot). Sampling points were geo-referenced and shown in Fig. I.

To characterize soil chemical properties, soil samples were taken at 0-20 $\mathrm{cm}$ depth in May and November (five samples per treatment per twice, corresponding to 20 samples as a whole)

A further set of soil samples was collected close to previous for nematodes analysis. The sampling was carried out with a hand auger ( $5 \mathrm{~cm}$ inside diameter) in March, May, July, September and November (5 replicates per treatment per five times, corresponding to 50 samples as a whole), from the $15 \mathrm{~cm}$ deep top layer of bulk soil after removing surface residues. For each soil sample, six scores were randomly sampled and then mixed to form one composite sample. Each sample was placed in a plastic bag, labelled and stored in a cold chamber at $4^{\circ} \mathrm{C}$.

To isolate and identify EPN strains, in each plot six scores were randomly collected using a hand shovel (15 cm depth), and then mixed to form one composite sample of approximately $2 \mathrm{~kg}$ each in March, May, July, September and November $(5$ replicates per treatment per five times, corresponding to 50 samples as a whole). The soil was transported in polythene bags to the laboratory.

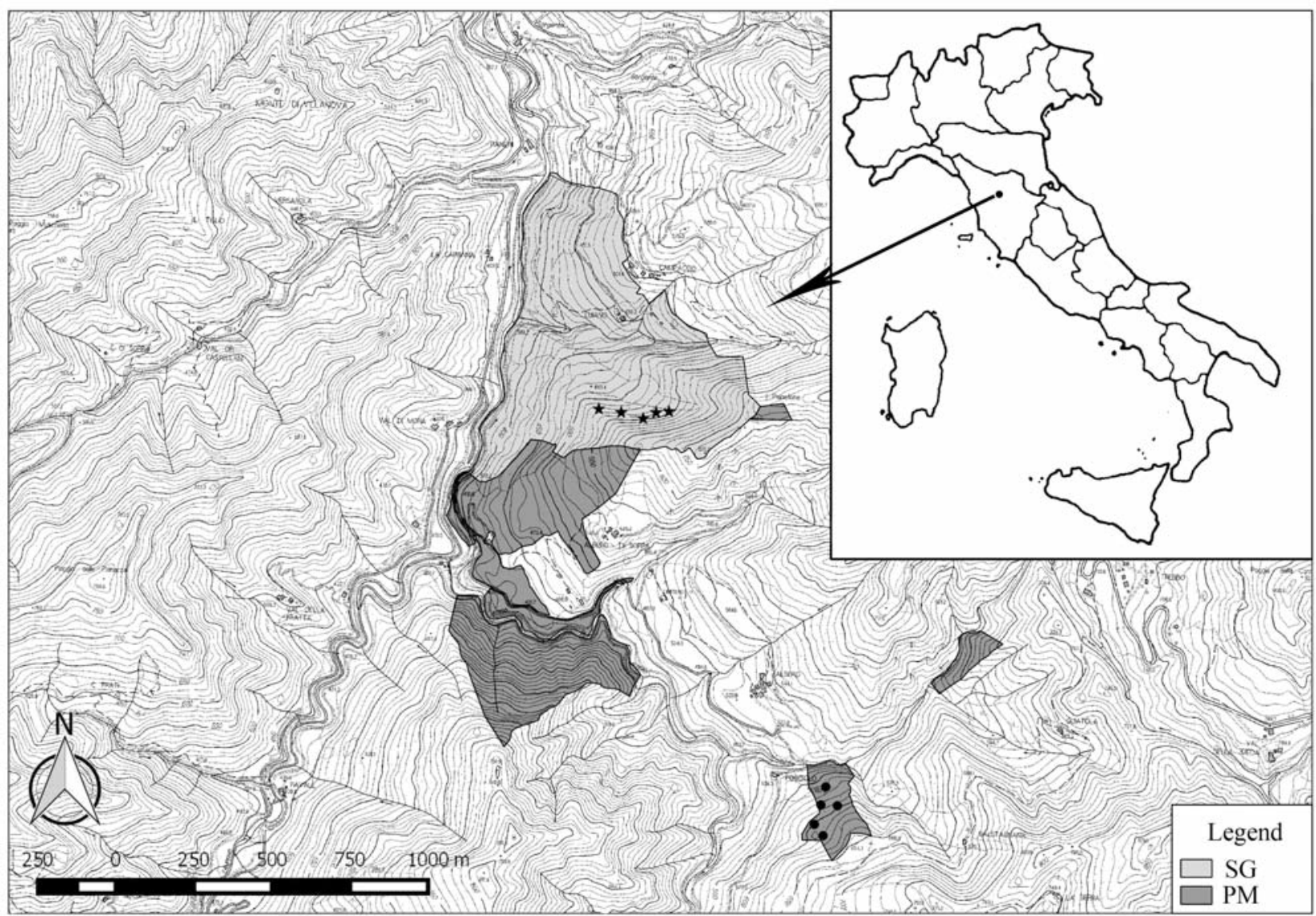

Fig. I - Location of the two farms where the survey was carried out in Marradi (Florence, Italy). The map shows geo-referenced points chosen for sampling. 
To determine the infestation levels by tortricids and curculionids the sampling was carried out in September, when the first infested fruits were prematurely dropped, and in November, when the most of them rain. For each plots all fruits that fell inside a sampling square corresponding to an area of $4 \mathrm{~m}^{2}$ (5 replicates per treatment per twice, corresponding 20 samples as a whole) were collected and stored at $4^{\circ} \mathrm{C}$ until check control.

\section{SOIL CHEMICAL ANALYSIS}

The soil samples were air-dried at room temperature and sieved through a $2 \mathrm{~mm}$ mesh for $\mathrm{pH}$ and available $\mathrm{P}$, then through a $0.5 \mathrm{~mm}$ mesh for total organic carbon (TOC) and total $\mathrm{N}$ analysis. The soil $\mathrm{pH}$ was measured potentiometrically in a 1:2.5 soil-water suspension. Available $\mathrm{P}$ was determined by BRAY and KURTZ methods (1945). Soil total organic C (TOC) was determined by hot oxidation with potassium dichromate and sulphuric acid according to SPRINGER and KleE (1954). Soil total N was analysed according to the Kjeldahl procedure (BREMMER, 1996), using a Tecator heating block for sample digestion (in concentrated $\mathrm{H}_{2} \mathrm{SO}_{4}+\mathrm{CuSO}_{4}$ catalyst) and a Foss 2300 Kjeltec apparatus for steam distillation/titration (RUTHERFORD et al., 2007).

\section{SOIL NEMATODE COMMUNITY ANALYSIS}

Nematodes were isolated from $100 \mathrm{ml}$ of each soil sample using the cotton-wood filter extraction methods, after being mixed. Nematodes were extracted for $48 \mathrm{~h}$ at room temperature, approximately $25^{\circ} \mathrm{C}$. Each nematode suspension was sieved through a $25 \mu \mathrm{m}$ sieve and the nematodes were counted at stereomicroscope (50X magnification). Nematodes were mounted on temporary slides and identified at higher magnification to genus or family level using keys from MAI and LYON (1962), Bongers (1990), MARINARI-PALMISANO and VinCIGUERRA (2014). Taxonomic families were assigned to a trophic grouping based on YeATES et al. (1993). Nematode communities were characterized using: (1) absolute abundance of individuals; (2) richness determined by counting the number of taxa; (3) the Maturity and Plant Parasitic indices (MI and PPI, respectively) after BONGERS (1990).

\section{ISOLATION OF EPN FROM SOIL}

The presence of entomopathogenic nematodes (EPNs) was assessed using the Galleria bait method (BEDDING and AKURST, 1975). The soil samples were placed in plastic containers and one steel mesh pocket containing two last larval instars of Galleria mellonella (L.) (Lepidoptera: Pyralidae) was placed in each container and kept at room temperature $\left(20 \pm 3^{\circ} \mathrm{C}\right)$. Cadavers with nematodes were placed on modified White traps (KAYA and STOCK, 1997). Juveniles emerging from the Galleria larvae were collected and stored in distilled water in $50 \mathrm{ml}$ tubes at $12^{\circ} \mathrm{C}$. Some of them were mounted on temporary slides and observed at up to microscope (1000X magnification) for morphological identification, and the remaining part was used for molecular characterization.

MOLECULAR ANALYSIS FOR IDENTIFICATION OF NEMATODES EMERGED FROM GALLERIA MELLONELLA

Five nematodes from each White trap were collected and put individually in $0.2 \mathrm{ml}$ tube containing $50.0 \mu 1$ InstaGene Matrix (Biorad), 1.5\% SDS and $2.5 \mu$ l Proteinase K 20.0 $\mu \mathrm{g} / \mu \mathrm{l}$. Samples were incubated at $55.0^{\circ} \mathrm{C}$ for 3 hours, Proteinase $\mathrm{K}$ was inactivated by heating at $96.0^{\circ} \mathrm{C}$ for 10 minutes and DNA was recovered with alcoholic precipitation adding $100.0 \mu \mathrm{l}$ of cold absolute ethanol. Pellets were air-dried and resuspended in $20.0 \mu \mathrm{l}$ of double distilled water.

The amplifications of ITS and 18S loci were performed using primer couples TW81-AB28 or $18 \mathrm{~S}-26 \mathrm{~S}$ and nem1-nem2 respectively (VRAIN et al., 1992; JOYCE et al., 1994; FouCher and WiLSON, 2002). The amplicons were sequenced at Genomics Research Centre (CREA-GPG). Species identifications were performed by homology search using BLAST algorithm. The nucleotide sequences determined in this study were deposited in the GenBank database under accession number KX036749 - KX036763. All species analyzed showed a unique haplotype for the considered loci. For this reason, only one sequence was deposited in GenBank database.

INFESTATION LEVEL OF CHESTNUT FRUITS BY INSECTS

All fruits were dissected and examined for the presence of insects. Tortricids and curculionids were identified on the basis of larvae morphology and the type of damage (PolLINI, 1998; BROwN and KomaI, 2008). The number of chestnut fruit infested by insect was expressed as percentages.

\section{STATISTICAL ANALYSIS}

Two-ways ANOVA was performed to assess the influence of management and seasonally on nematode taxa, indicators of nematode community structure (MI, PPI), proportion of sentinel G. mellonella hosts infected by nematodes and indicators of soil chemical properties $(\mathrm{pH}$, available $\mathrm{P}$, TOC and total $\mathrm{N}$ ). When the F-test was significant at $\mathrm{P}<0.05$, treatment means were compared using the StudentNewman-Keuls test using CoStat statistical software package (http://www.Cohort.com/costat.html).

Moreover, nematode communities were compared using multi-variate methods provided by the Past analysis package (HAMMER et al., 2001) (http://folk.uio.no/ ohammer/past). EPNs communities were compared using analysis of similarities (ANOSIM), multidimentional scaling (MDS) and SIMPER analysis based on the BrayCurtis similarity index, nearest-neighbor. The nematode abundance data were transformed using the square root. Bonferroni correction $P$ value was applied. Canonical Correspondence Analysis (CCA) was carried out in order to link nematode communities (abundance of nematode taxa) and soil variable (texture, soil $\mathrm{pH}$, organic $\mathrm{C}$, total $\mathrm{N}$, and available $\mathrm{P}$ ). Only the significant environmental axes are taken into account and are represented by vectors. The length of the vectors indicates the importance of the environmental variable with other variables; vectors in the same direction are positively correlated, while vectors pointing in opposite directions are negatively related. The statistical significance of the relationship between community and environmental variables was assessed by permutation test of both the first ordination axis and the combination of both the first and second axes.

Student's $t$-test (significant at $\mathrm{P}<0.05$ ) was used to compare differences between PM and SG for insect infestation levels. The infestation percentages were arcsine transformed.

\section{RESULTS}

\section{SOIL CHEMICAL PROPERTIES}

Average of replicate values of soil $\mathrm{pH}$, available $\mathrm{P}$, organic $\mathrm{C}$, total $\mathrm{N}$ and relative statistic analyses are reported in Fig. II. Soil pH resulted significantly different between 

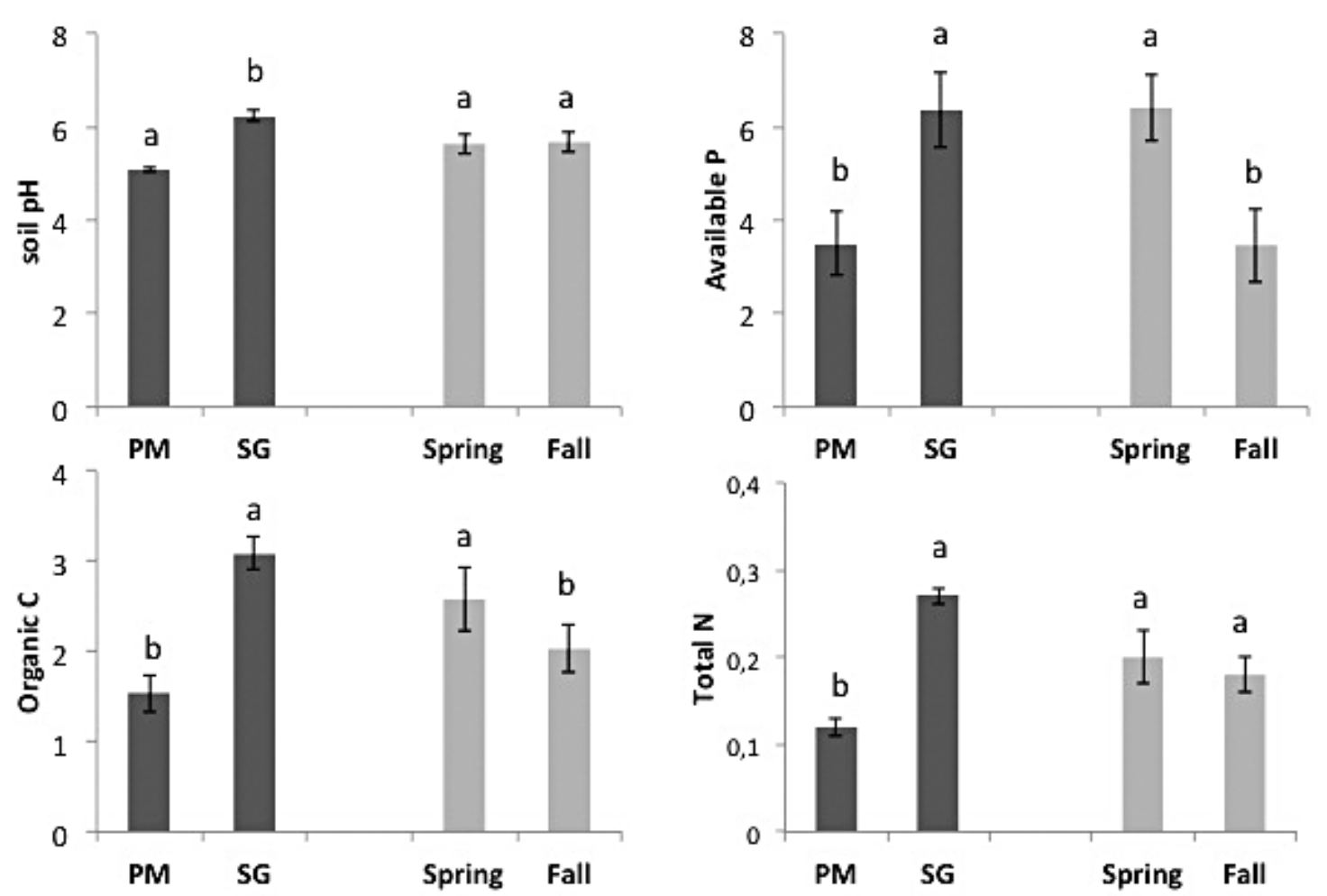

Fig. II - Effect of managements and season on soil chemical properties. Standard errors are reported. Levels of significance are indicated by letters $\mathrm{a}, \mathrm{b}$ for $\mathrm{P}<0.05$ (Student-Newman-Keuls test).

the soil managements, evidencing lower values in PM $(5.08 \pm 0.05)$ than SG $(6.24 \pm 0.12)$. No difference was found seasonally. The content of available $\mathrm{P}$ was significantly higher in SG $\left(6.38 \pm 0.81 \mathrm{mg} \mathrm{kg}^{-1}\right)$ than PM $(3.50 \pm 0.67 \mathrm{mg}$ $\left.\mathrm{kg}^{-1}\right)$. Moreover, this parameter showed the highest values in spring. The same trend was registered for organic $\mathrm{C}$ with significant differences between SG and PM $(3.09 \pm 0.20$ and $1.53 \pm 0.18 \mathrm{~g} \mathrm{~kg}^{-1}$, respectively) and seasonally. Finally, total $\mathrm{N}$ showed only significant differences for management, with $0.27 \pm 0.01$ and $0.12 \pm 0.01 \mathrm{~g} \mathrm{~kg}^{-1}$ for $\mathrm{SG}$ and $\mathrm{PM}$, respectively.

SOIL NEMATODE COMMUNITY STRUCTURE AND DYNAMICS

The effect of management practices and season on the abundance of nematode taxa is reported in Table1.Thirtyfive different genera, belonging to twenty-two plant parasitic and free-living nematode families, were identified in soil samples collected from SG and PM farms during the growing season. In general, only families Rhabditidae, Dorylaimidae, Tylenchidae and Paratylenchidae were prominent throughout the year. The families Diplogasteridae, Heteroderidae and Meloidogynidae were found in PM, while the families Mylonchulidae, Hemicycliophoridae and Trichodoridae were present in SG. Nematode abundance and taxa richness were similar under SG than PM, even though the abundance showed strong variability in PM and explained the high value of standard errors. The proportion of nematodes in the feeding groups was also similar under both managements: bacterial feeders, omnivores and plant parasitic nematodes were the most representative groups, while abundance of fungal feeders and predators was low in both regimes. The significant difference between these two systems was that Paratylenchidae family was more prominent in PM and
Seinuridae family in SG. On the contrary significant differences were observed for seasonal sampling. The highest values of total abundance and taxa richness were reported in July. The trophic group composition also varied more as a result of seasonal fluctuation than of management. Bacterial feeders and omnivores showed the same seasonal trend; the abundance of these groups was lower in summer than during the other seasons. The alternative effect for plant parasitic nematodes was reported that were dominated in summer (over 60\%).

Averages of MI, PPI indicators according to the management and season are reported in Table 1. No difference was showed between managements for both indices. The MI values ranged between 2.58 in SG and 2.78 in PM indicating the presence of generalist and opportunist species. The highest PPI was observed at the first sampling, and declined by the later sampling dates. Changes in the PPI were driven mostly by shift in abundance of Tylenchidae and Paratylenchidae ( $c p-2)$; families of persister nematodes, like Longidoridae $(c p-5)$ and Trichodoridae $(c p-4)$ were present principally in March.

With regard to nematodes species emerged from sentinel G. mellonella larvae, a seasonal effect of nematodes infection on G. mellonella was detected with a lower rate of infection in September than in other months. However, effects of different management regime, and the interaction between management and season, were clearly not significant (Fig. III, 1). Forty-two isolates were collected from sentinel wax-worms. Among them, $71.4 \%$ of isolated proved capable of killing insect larvae. Based on the molecular analysis and their morphological characters, the nematode isolates recovered were identified as seven species belonging to Steinernema, Rhabditis, Oscheius and Pristionchus genera. In particular, the species Rhabditis 


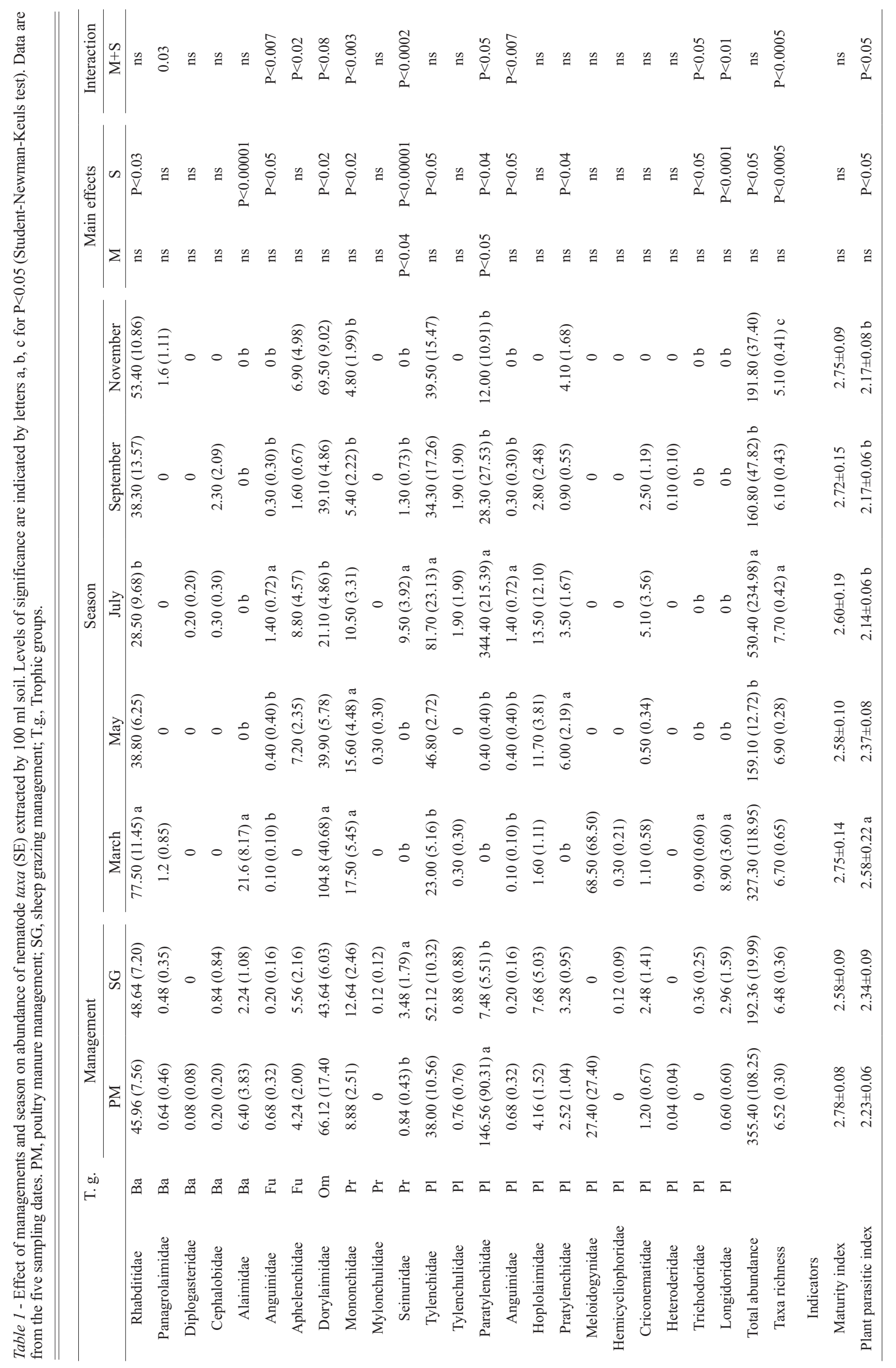




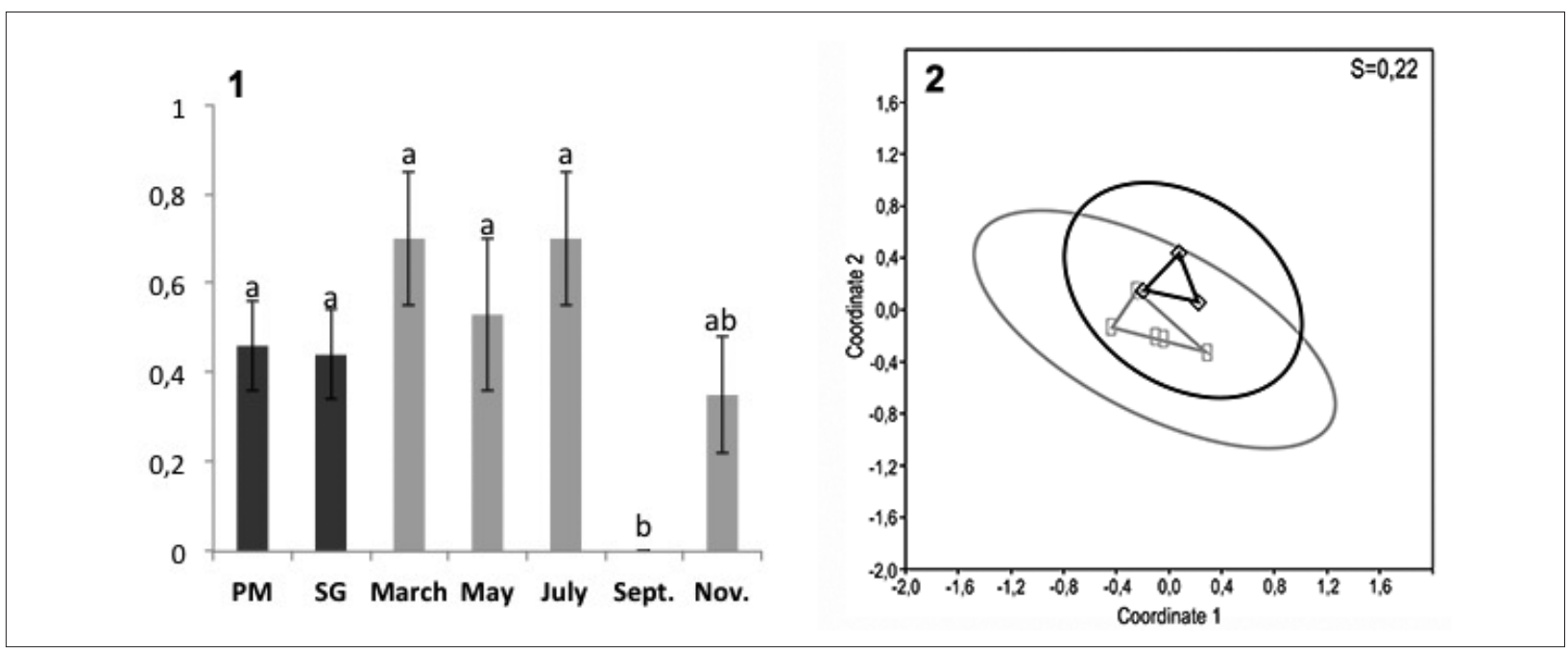

Fig. III - Nematodes emerged from sentinel G. mellonella larvae. 1. Proportion of sentinel G. mellonella hosts infected by nematodes. Levels of significance are indicated by letters $a, b$ for $\mathrm{P}<0.05$ (Stuedent-Newman-Keuls test). PM, poultry manure management; $\mathrm{SG}$, sheep grazing management. 2. MDS analysis based on the Bray-Curtis similarity index on nematodes community emerged from sentinel $G$. mellonella larvae. $95 \%$ ellipses and Stress test are reported. Gray rectangle, PM; black square, SG.

terricola Dujardin, Steinernema sp., Oscheius onirici Torrini, Mazza, Carletti, Benvenuti, Roversi, Fanelli, De Luca, Troccoli, Tarasco and Pristionchus sp. were isolated in both regimes, while Oscheius tipulae Lam \& Webster and Pristionchus entomophagus Kreis were found only in SG. The MDS analysis on abundance of nematodes species emerged from Galleria larvae showed a partial separation between SG and PM (Fig. III, 2). ANOSIM analysis confirmed these data: $\mathrm{R}$ value for SG-PM comparison was 0.4 with $\mathrm{P}$ value of 0.03 demonstrating a significant difference of SG to PM. The difference was explained by SIMPER analysis with $81.2 \%$ of average dissimilarity. Differences were mainly due to the higher proportion of $O$. tipulae in $\mathrm{SG}$ and $R$. terricola in PM that together contributed to $50 \%$ of dissimilarity.

\section{RELATIONSHIP AMONG SOIL VARIABLES ON NEMATODE TAXA} AND ABUNDANCE OF NEMATODES TAXA

In CCA conducted between nematode community variables (abundance of nematodes taxa) and soil significant variables (clay, soil $\mathrm{pH}$, organic $\mathrm{C}$ and total $\mathrm{N}$ ) in $\mathrm{PM}$ and SG, the axis 1 explained $65.3 \%$ of total variation, it was significant for $P<0.05$ and it was dominated by $\mathrm{pH}(0.16)$. The second canonical axis explained $30.7 \%$ of total variation, it was significant for $\mathrm{P}<0.01$ and it was dominated by the following soil variables: clay $(0.45)$, organic $\mathrm{C}$ ($0.42)$, total $\mathrm{N}(-0.40)$ and $\mathrm{pH}(-0.35)$. In the ordination diagram definite by the first and second axis (Fig. IV), SG replicates were separated to the left-hand side of the biplot, while PM replicates showed a weak separation. Significant community variables were: 1) the families of Cephalobidae, Trichodoridae, Longidoridae and Hemicycliophoridae resulted positively influenced by $\mathrm{pH} ; 2$ ) the families of Mylonchulidae and Seinurae, their dominant drive were $\mathrm{pH}$ and total $\mathrm{N}$; 3 ) the families of Paratylenchidae, Meloidogynidae and Heteroderidae were inversely correlated with organic $\mathrm{C}$ and total $\mathrm{N}$.

\section{INFESTATION LEVEL OF CHESTNUT FRUITS BY INSECTS}

Chestnut fruit infestation by insects differed strongly between managements, being considerably higher in PM (Fig. V). In September, the prematurely dropped chestnuts were infested by tortricids for $87.9 \%$ and $58.2 \%$ in PM and
SG, respectively. When the most of fruits rain in November, the total infestation was $54.3 \%$ and $34.3 \%$ in PM and SG, respectively. Based on the morphological characters of larvae and the damage types, the insect larvae recovered were identified as four species belonging to the families of Tortricidae and Curculionidae. In general, only tortricids were prominent throughout the monitored year. In particular, Pammene fasciana (L.) was present in September, while Cydia splendana (Hb.) and Cydia fagiglandana (Zel.) were found in November. Curculio elephas Gyll. (Fam. Curculionidae) was found only in September with a low level of infestation.

\section{DISCUSSION}

EFFECT OF SOIL MANAGEMENTS ON SOIL FERTILITY

SG provide more nutrients and organic matter $(5 \mathrm{U}$ of sheep per year produce $24.6 \mathrm{~kg} / \mathrm{ha} \mathrm{N}, 6.3 \mathrm{~kg} / \mathrm{ha} \mathrm{P}_{2} \mathrm{O}_{5}, 417$ $\mathrm{kg} /$ ha organic C) than PM, that was distributed only on crown cover acting like a mineral fertilizer without amended effect $\left(8 \mathrm{~kg} /\right.$ plant bring per year $11.5 \mathrm{~kg} / \mathrm{ha} \mathrm{N}, 11.5 \mathrm{~kg} / \mathrm{ha} \mathrm{P}_{2} \mathrm{O}_{5}, 92$ $\mathrm{kg} /$ ha organic $\mathrm{C}$ ). In $\mathrm{SG}$, the top soil organic $\mathrm{C}$ content was $3 \%$ over the critical threshold (2\%) for soil quality in temperate regions (LIEBIG and DORAN, 1999); on the contrary in PM soil organic C was near to $1.7 \%$, a typical value of agricultural soil. The same differences were found in total $\mathrm{N}$ and available $\mathrm{P}$ content. These differences were caused by the enrichment of soil with animal excreta. HOOGENDOORN et al. (2011) and PARSONS et al. (2013) sustained that the sheep, as heterotrophs, substantially uncouple the $\mathrm{C}$ and $\mathrm{N}$ cycles: the annual quantity of $\mathrm{C}$ ingested by grazing animals is for $70 \%$ emitted as $\mathrm{CO}_{2}$ by breathing and only approximately $30 \%$ is recycled to the soil surface as dung; instead, some $70 \%$ of $\mathrm{N}$ is excreted in urine. Our results agree with this data. In fact, the percentage increment of total $\mathrm{N}$ was higher $(261 \%)$ than increment of organic C (201\%). This explained also the higher value of soil $\mathrm{pH}$ under SG than PM due to salinity effect of uric acid. Moreover, a positive correlation was found between the $\mathrm{N}$ and $\mathrm{C}$ amount applied and the total $\mathrm{N}$ and organic $\mathrm{C}$ measured in soil. On the contrary, the $\mathrm{P}$ amount brought with poultry manure was higher than sheep grazing, but the soil available P content was higher in SG than PM. 


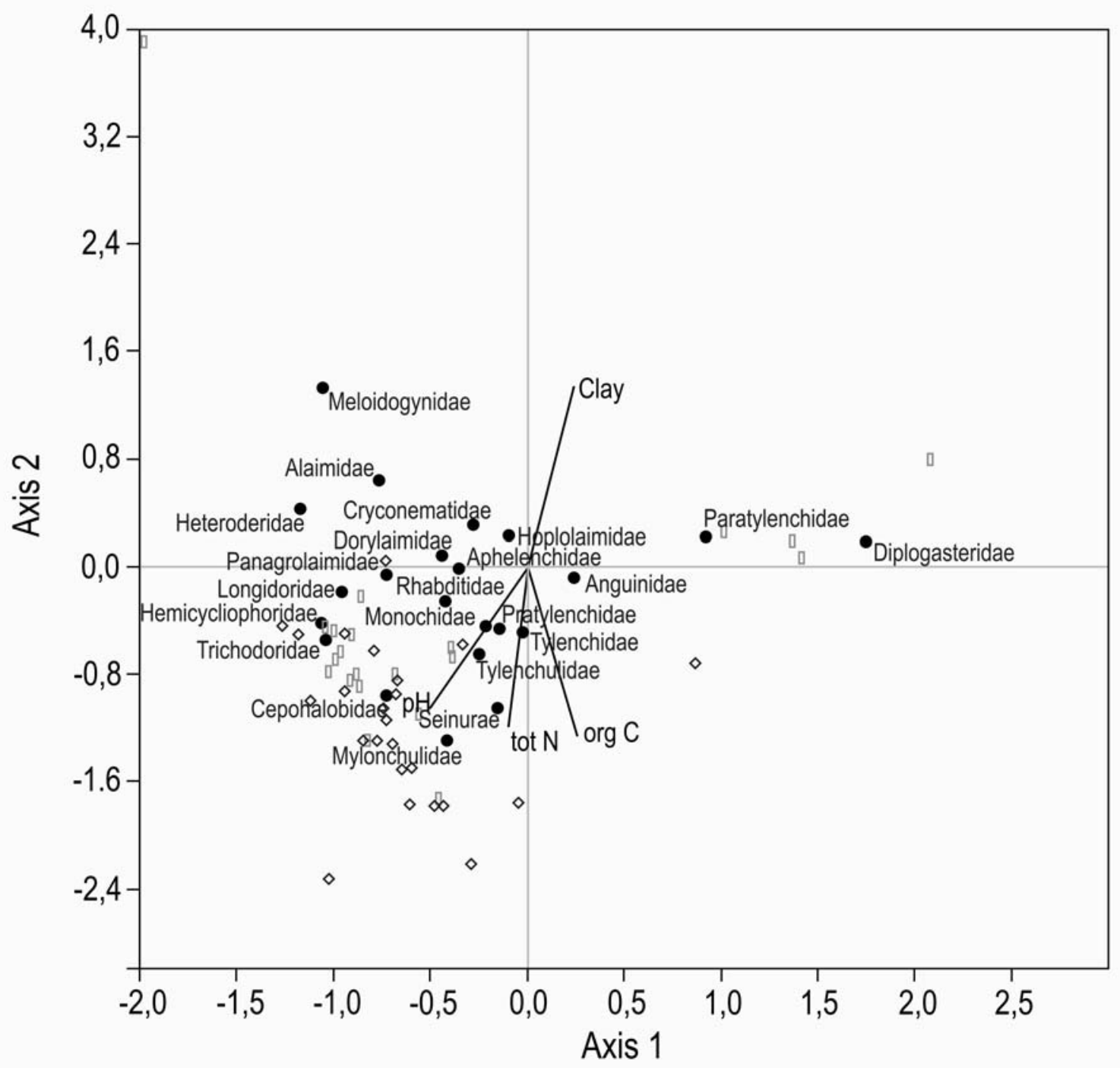

Fig. IV - Scatter plot of CCA ordination showing relationships between environmental variables (significant soil properties) and nematode taxa abundance. Percentage of explained variance were 65.3\% $(\mathrm{P}<0.05)$ and $30.7(\mathrm{P}<0.01)$ for axis 1 and 2, respectively. Gray rectangle, PM; black square, $\mathrm{SG}$

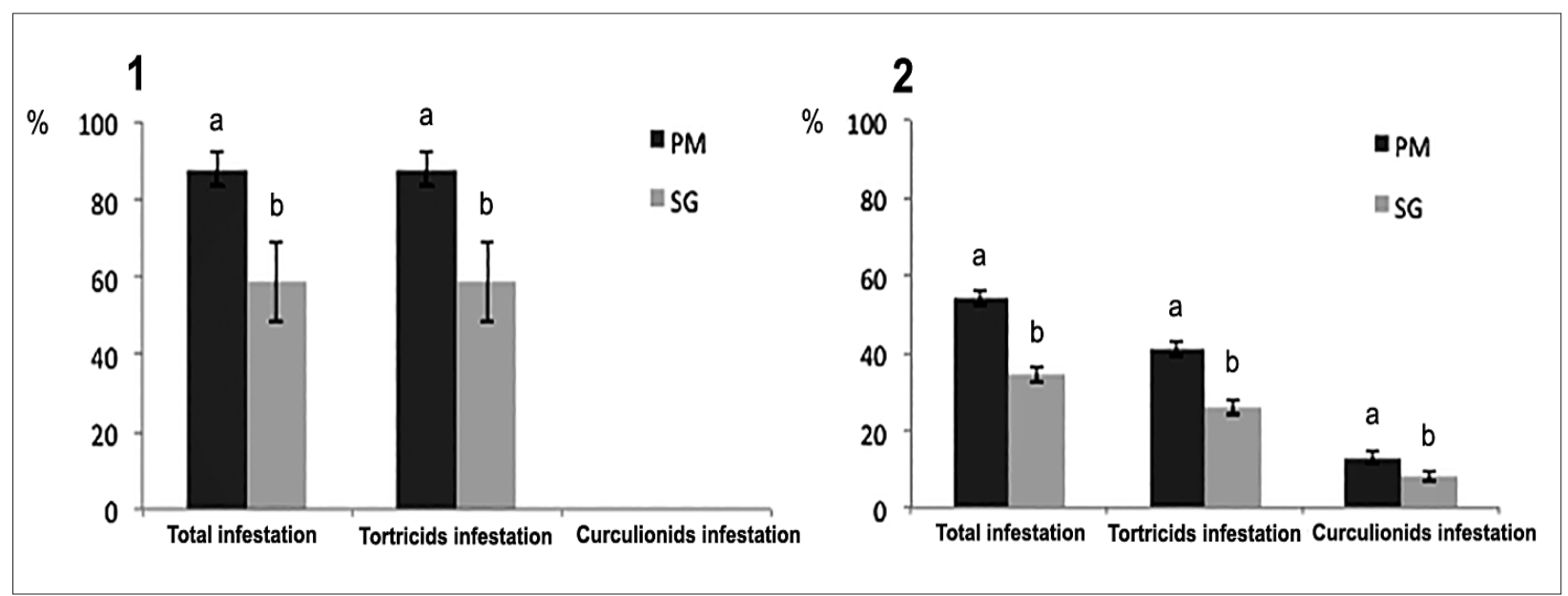

Fig. V - Infestation percentage of tortricids and curculionids on prematurely dropped chestnuts in September (1) and on rained in November (2). Levels of significance are indicated by letters a, b for $\mathrm{P}<0.05$ ( $t$-Students test). PM, poultry manure management; SG, sheep grazing management. 
Probably, this difference is caused by immobilization of $\mathrm{P}$ in PM due to low pH $(\sim 5.0)$. As reported by Wenzel et al. (1994), a seasonal variation in the amount of C, N and P was measured; this is an effect of the annual cycle of the deciduous forest, which, in temperate climate, supplies organic matter to the soil with varying intensity over the year.

\section{EFFECT OF SOIL NEMATODE COMMUNITY STRUCTURE AND ITS DYNAMICS}

In accordance with Hodges (1991) and WIDMER et al. (2002), the greatest accumulation of organic matter under SG provided stability in nematode community structure and suppressed the plant pathogen. As reported by BARKER and KOENNING (1998), the population of plant parasitic nematodes decreased in SG, while strong fluctuations in Paratylenchidae and Meloidogynae families were found in PM. Gonzalez and CANTO-SAEnz (1993) reported the efficacy of poultry manure amendment to soil for the control of plant-parasitic nematodes on vegetable crops, but in our case, the low and localized quantity of poultry manure applied to soil does not have the amended effect. Other authors (YeATES et al., 1997; MULDER et al., 2003) have reported an increase of fungal-feeder nematodes under organic managements, but in our study the fungal feeder nematode abundance was low. Instead, our results were similar to SCHON et al. (2011) and Li et al. (2014) that indicate lower abundance of fungal feeder nematode as associated with less intensive management. In fact, the MI values confirm that organic regimes are characteristic of perennial crops without strong inputs. Moreover, the increase in soil $\mathrm{pH}$ promoted the abundance of Cephalobidae, Seinurae, Mylonchulidae, Trichodoridae, Longidoridae and Hemicycliophoridae families.

The temporal trend within this study suggested that the community composition changed from bacterial to plant parasitic domination during summer period. According to our results, SoHLENIUS (1985) reported that the colonizers belonging to Rhabditidae family were higher in number during wet and cold conditions. In the summer, changes in community structure were reflected by the PPI, which shifted from a relatively diverse community structure to a simpler one with a decrease in number of omnivores and increase of plant parasitic nematodes belonging to $c p 2$ class.

By considering the EPNs, more attention was given to their biodiversity species level and their possible effect to control tortricids and curculionids. The species composition of nematodes emerged from sentinel G. mellonella larvae was evaluated by similarity analysis and resulted difference between SG and PM. O. tipulae and R. terricola were the most frequently recoded species and dominated in SG and PM, respectively. Moreover, as reported by DZIĘGIELEWSKA et al. (2012), the soil fluctuation was found seasonally. Only Steinernema sp. and $O$. onirici were recognized as EPNs (KAYA and GAUgler, 1993; TORRINI et al., 2015); in following study, their abundances were low and similar in both managements. The other species are considered necromenic, or not associated with specific bacterial species and their microflora may possibly vary with habitat and/or hosts (BAïlLE et al., 2008; RAE et al., 2008). This suggests that the native EPNs communities in both farms could not effectively contribute to control tortricids and weevils infestations.

\section{CONTROL OF CHESTNUT FRUITS INFESTATION}

BONAL and MUÑOZ (2007) reported similar results that confirm sheep are major predators of tortricid and weevil larvae. In SG, the feeding of sheep on drop fruits was helpful to suppress the number of larvae; in November, the infestation level was $34.3 \%$ in SG, while $54.3 \%$ in PM. The sheep feeding begins already in September when the premature abscission of infested chestnut fruits occurs. For this reason, several authors suggested that premature abscission is a plant defensive mechanism (g.e. BONAL and MUÑOZ, 2007).

\section{CONCLUSION}

By evaluating changes between indicators of fertility condition, indicators of nematode community structure and indicators of phytophagous levels, we were able to quantify the effects of a moderate livestock grazing regime in sweet chestnut cultivation. Its effect on soil fertility and on tortricids and weevils is very relevant. Compared to $\mathrm{PM}, \mathrm{SG}$ increases twice the organic $\mathrm{C}$, total $\mathrm{N}$ and available $\mathrm{P}$, and it reduces by half the loss of fruit by pests. Moreover, the greater accumulation of organic matter favour indirect enhancement the other soil properties like physical structure and water holding capacity. Organic matter plays a vital role in stability of nematode community structure as it promote the soil fertility by increasing the species closely linked to its content and suppressing the plant pathogen. Instead, the abundance and the efficiency of native entomopathogenic nematodes do not contribute to control insect pests. This study has highlighted that a moderate grazing represent a desirable practice in sweet chestnut organic farming. Further studies and accumulation of data would provide greater confidence in grazing effects on this environment.

\section{ACKNOWLEDGEMENT}

This work was supported by Italian National Project BIOTECNOCAST "Controllo biologico e biotecnico del cinipide orientale e dei principali fitofagi del Castagno in un contesto di produzione biologica" financed by Ministero delle Politiche Agricole e Forestali. We are very grateful to Mr. Perfetti, Mr. Alpi and Mr. Valgimigli for providing monitoring fields. We also grateful to Giovanni Cortini and Lorenzo Marziali for assistance during sampling.

\section{REFERENCES}

Aguin-Pombo D., Arraiol A., Aguiar A.F., Freitas E., ANGELI G., 2008 - Large infestation of chestnut by Cydia moths in Madeira Island: monitorization of Cydia splendana populations with pheromone lures. - Acta Horticulturae, 784: 175-180.

BAÏlle D., BARrière A., FÉliX M.A., 2008 - Oscheius tipulae, a widespread hermaphroditic soil nematode, displays a higher genetic diversity and geographical structure than Caenorhabditis elegans. - Molecular ecology, 17: 1523-1534.

BARKer K.R., Koenning S.R., 1998 - Developing sustainable systems for nematode management. - Annual review of phytopathology, 36: 165-205.

BEDDING R., AKURST R., 1975 - A simple technique for the detection of insect parasitic rhabditid nematodes in soil. Nematologica, 21: 109-110.

BERRYMAN A.A., 1996 - What causes population cycles of 
forest Lepidoptera? -Trends in Ecology \& Evolution, 11: $28-32$.

Bonal R., MuÑoz A., 2007 - Multi-trophic effects of ungulate intraguild predation on acorn weevils. Oecologia, 152: 533-540.

BONGERS T., 1990 - The maturity index: an ecological measure of environmental disturbance based on nematode species composition. - Oecologia 83: 14-19.

BOUCHER D.H., SORK V.L., 1979 - Early drop of nuts in response to insect infestation. - Oikos, 33: 440-443.

Bounous G., 2004 - The chestnut: a multipurpose resource for the new millennium. -III International Chestnut Congress, Chaves, Portugal, October 20-23, 693: 33-40.

Bray R.H., KURTz L.T., 1945 - Determination of total organic and available forms of phosphorus in soils. - Soil Sci., 59:39-45.

BREMNER J., 1996 - Nitrogen-total. In: Sparks D., Bartels J., Birham J. Eds., Methods of soil analysis. Chemical methods. SSA, Madison, Wisconsin, pp. 1085-1121.

Brown J.W., Komai F., 2008 - Key to larvae of Castaneafeeding Olethreutinae frequently intercepted at US portsof-entry. - Tropical Lepidoptera, 18: 2-4.

Cole L.J., Pollock M.L., Robertson D., Holland J.P., MC CRACKEN D.I., HARRISON W., 2010 - The influence of fine-scale habitat heterogeneity on invertebrate assemblage structure in upland semi-natural grassland. Agriculture, ecosystems \& environment, 136: 69-80.

Dennis P., Young M., Gordon I., 1998 - Distribution and abundance of small insects and arachnids in relation to structural heterogeneity of grazed, indigenous grasslands. - Ecological Entomology, 23: 253-264.

DzięGielewska M., Myśków B., Adamska, I., Czerniawska B., 2012 - Seasonal Dynamics of the Activity of Entomopathological Nematodes (Steinernematidae and Heterorhabditidae). In: Selected Greens of Szczecin. - Ecological Chemistry and Engineering (Part A), 19: 601-607.

Ferris H., Bongers T., De Goede R., 2001 - A framework for soil food web diagnostics: extension of the nematode faunal analysis concept. - Applied Soil Ecology, 18: 1329.

Foucher A., Wilson M., 2002 - Development of a polymerase chain reaction-based denaturing gradient gel electrophoresis technique to study nematode species biodiversity using the $18 \mathrm{~s}$ rDNA gene. - Molecular Ecology Notes, 2: 45-48.

GAUGLER R., 2002 - Entomopathogenic nematology. CABI Publishing, Wallingford, 393 pp.

GONZALEZ A., CANTO-SAENZ M., 1993 - Comparison of five organic amendments for the control of Globodera pallida in microplots in Peru. - Nematropica, 23: 133-139.

Hammer Ø., Harper D., RyAn P., 2001 - PASTPAlaeontological STatistics, ver. 1.89. - Palaeontologia electronica, 4: 1-9.

Hodges R., 1991 - Soil organic matter: its central position in organic farming. In: Advances in "Soil Organic Matter Research: The Impact on Agriculture and the Environment". Royal Society of Chemistry, Cambridge, pp. 355-364.

Hoogendoorn C., Bowatte S., Tillman R., 2011 - Simple models of carbon and nitrogen cycling in New Zealand hill country pastures: exploring impacts of intensification on soil $C$ and $N$ pools. - New Zealand Journal of Agricultural Research, 54: 221-249.

Joyce S., Reid A., Driver F., Curran J., 1994 Application of polymerase chain reaction (PCR) methods to the identification of entomopathogenic nematodes. In:
Burnell, A.M., Ehlers, R.U., Masson, J.P. Eds., COST 812 Biotechnology: Genetics of Entomopathogenic Nematode-Bacterium Complexes, St. Patrick's College, Maynooth, Co. Kildare, Ireland, pp. 178-187.

Kaya H.K., Gaugler R., 1993 - Entomopathogenic nematodes. - Annual review of entomology, 38: 181-206.

KAYA H.K., STock P., 1997 - Techniques in insect nematology. In: Lacey, L.A. Ed., Manual of techniques in insect pathology. Academic Press, London, pp. 281-324.

Li X., Liu Z., Shi W., YANG D., TARAsco E., 2014 - Effects of organic and other management practices on soil nematode communities in tea plantation: a case study in southern China. - J. Plant Nutr. Soil Sci., 177: 604-612.

Liebig M.A., Doran J.W., 1999 - Impact of Organic Production Practices on Soil Quality Indicators. - Journal of Environmental Quality, 28: 1601-1609.

Mai W.F., Lyon H.H., 1962 - Pictorial key to genera of plant parasitic nematodes. Plates reproduced by Art Craft of Ithaca, Inc. Ithaca, New York.

Marinari-Palmisano A., Vinciguerra M., 2014 Classificazione dei nematodi. In: Ambrogioni, L., d'Errico, F.P., Greco, N., A, M.-P., Roversi, P.F. Eds., Nematologia Agraria generale e applicata. Società Italiana di Nematologia Bari, pp. 23-42.

Moon D.C., Stilling P., 2002 - The influence of species identity and herbivore feeding mode on top-down and bottom-up effects in a salt marsh system. - Oecologia, 133: 243-253.

Mulder C., Zwart D., Van Wijnen H., Schoten A., BREURE A., 2003 - Observational and simulated evidence of ecological shifts within the soil nematode community of agroecosystems under conventional and organic farming. - Functional Ecology, 17: 516-525.

Neri L., Dimitri G., SACchetti G., 2010 - Chemical composition and antioxidant activity of cured chestnuts from three sweet chestnut (Castanea sativa Mill.) ecotypes from Italy. - Journal of food composition and analysis, 23: 23-29.

Paparatti B., Speranza S., 2004 - Management of Chestnut Weevil (Curculio spp.) 1, Insect Key-Pest in Central Italy. - III International Chestnut Congress, Chaves, Portugal, October 20-23, 693: 551-556.

Parsons A., Thomley J., Newton P., Rasmussen S., ROWARTH J., 2013 - Soil carbon dynamics: the effects of nitrogen input, intake demand and off-take by animals. Science of The Total Environment, 465: 205-215.

Pollini A., 1998 - Manuale di entomologia applicata. Edagricole-Edizioni Agricole, $1462 \mathrm{pp}$.

Rae R., Riebesell M., Dinkelacker I., Wang Q., Hermann M., Weller A.M., Dieterich C., Sommer R.J., 2008 - Isolation of naturally associated bacteria of necromenic Pristionchus nematodes and fitness consequences. - Journal of Experimental Biology, 211: 1927-1936.

Rutherford P., Mc Gill W., Arocena J., Figueiredo C., 2007 - Total nitrogen. Soil sampling and methods of analysis; 2nd ed. CRC Press, Boca Raton, FL, 239-250 $\mathrm{pp}$

SCHON N., MACKAy A., Minor M., 2011 - Soil fauna in sheep-grazed hill pastures under organic and conventional livestock management and in an adjacent ungrazed pasture. - Pedobiologia, 54: 161-168.

SOHLENIUS B., 1985 - Influence of climatic conditions on nematode coexistence: a laboratory experiment with a coniferous forest soil. - Oikos, 44: 430-438.

SPRINGER U., KleE J., 1954 - Prufung der Leistungsfa higkeit von einigen wichtigen Verfahren zur Bestimmung 
des Kohlenstoffs mittels Chromschwefelsaure sowie Vorschlag einer neuen Schnellmethode. - J. Plant Nutr. Soil Sci., 64: 1-26.

Strauss S.Y., Zangerl A.R., 2002 - Plant-insect interactions in terrestrial ecosystems. Blackwell Publishing: Oxford, UK, 77-106 pp.

Torrini G., Mazza, G., Carletti B., Benvenuti C., Roversi P.F., Fanelli E., De Luca F., Troccoli A., TARASCO E., 2015 - Oscheius onirici $s p$. n. (Nematoda: Rhabditidae): a new entomopathogenic nematode from an Italian cave. - Zootaxa, 3937: 533-548.

VINCIGUERRA M., Clausi M., 2006 - Biological control of chestnut insect pests by means of entomopathogenic nematodes. - Advances in Horticultural Science, 20: 4044.

VRain T.C., WakarchuK D.A., LÉvesque A.C., Hamilton R.I., 1992 - Intraspecific rDNA restriction fragment length polymorphism in the Xiphinema americanum group. - Fundamental and Applied Nematology, 15: 563 573

Wenzel W., Alge G., Brandstetter A., Blum W., 1994 Seasonal changes of Ph, organic carbon, total nitrogen, calcium and aluminum in a forest topsoil. - Ecologie, 25: 211-215.

Widmer T., Mitkowski N., ABAwi G., 2002 - Soil organic matter and management of plant-parasitic nematodes. Journal of nematology, 34: 289.

Yeates G., Bardgett R., Cook R., Hobbs P., Bowling P., POTTER J., 1997 - Faunal and microbial diversity in three Welsh grassland soils under conventional and organic management regimes. - Journal of Applied Ecology, 34: 453-470.

Yeates G., Bongers T., De Goede R., Freckman D., GEORGIEVA S., 1993 - Feeding habits in soil nematode families and genera in outline for soil ecologists. Journal of nematology, 25: 315-331. 